\title{
Exploring Patient-Reported Costs Related to Hepatitis C on the Medical Crowdfunding Page GoFundMe ${ }^{\circledast}$
}

\author{
T. Joseph Mattingly II ${ }^{1} \cdot$ Karen $\mathrm{Li}^{2} \cdot{\text { Arnold } \mathrm{Ng}^{2} \cdot \text { Tieu-Long Ton- } \mathrm{Nu}^{2} \cdot \text { Jennifer Owens }}^{3}$
}

Accepted: 17 September 2020 / Published online: 30 September 2020

(c) The Author(s) 2020

\begin{abstract}
Background Successful medical crowdfunding campaigns may alleviate or even eliminate the financial burden of expensive, cumulative medical bills. GoFundMe ${ }^{\circledR}$ crowdfunding pages for hepatitis $\mathrm{C}$ virus (HCV) patients were reviewed and analyzed to better understand the characteristics that contribute to a successful fundraising campaign in a disease often associated with patients with a lower social standing or stigma.

Methods A pilot cross-sectional study of all publicly available GoFundMe ${ }^{\circledR}$ crowdfunding pages was conducted for posts related to HCV on GoFundMe ${ }^{\circledR}$ in June 2019. Similar to data extraction steps in a systematic literature review, page data were reviewed to identify whether the source of the patient's HCV infection was disclosed, if disclosed then how did the patient report contracting the disease, and all costs reported in the description as part of the rationale for requesting funds. Descriptive statistics of category and numeric variables were reported for the full sample, and exploratory analyses were conducted to determine any potential associations with categorical variables and the amount of donations received, categorized as small ( $<$ US\$1000), moderate (US\$1000-4999), and large ( $\geq$ US\$5000).

Results A total of 685 unique GoFundMe ${ }^{\circledR}$ pages were included in the analysis. Only 30\% (206/685) of the pages disclosed the source of HCV infection. Of those that disclosed a virus source, $86 \%(177 / 206)$ described a source that appeared more socially desirable to our research team (blood transfusion, organ transplant, occupational exposure, etc.). In terms of actual donations received by a page, $46 \%$ (312/685) were less than US $\$ 1000,38 \%(262 / 685)$ were between US $\$ 1000$ and US\$4999, and $16 \%(111 / 685)$ were US $\$ 5000$ or more. Disclosing the virus source was associated with a higher donation category $(p=0.0099)$.
\end{abstract}

Conclusion These exploratory findings yield important insights, both for patients or caregivers seeking support on GoFundMe ${ }^{\circledR}$ crowdfunding websites and for researchers interested in exploring the types of costs self-reported by patients in their public requests for financial assistance.

\section{Key Points for Decision Makers}

Hepatitis $\mathrm{C}$ virus (HCV) patient pages that disclosed more information (source of virus and types of costs) were associated with higher levels of donations received per page.

T. Joseph Mattingly II

jmattingly@rx.umaryland.edu

1 Department of Pharmaceutical Health Services Research, University of Maryland School of Pharmacy, 220 Arch Street, 12th Floor, Room 224, Baltimore, MD 21201, USA

HCV GoFundMe ${ }^{\circledR}$ crowdfunding pages include a wide range of health and non-health costs, providing a potential source of patient-reported information for health economists interested in building more comprehensive and patient-centered economic evaluations.

2 University of Maryland School of Pharmacy, Baltimore, MD, USA

3 University of Maryland Graduate School, Baltimore, MD, USA 


\section{Introduction}

As the costs of health care rise, patients experiencing increased out-of-pocket (OOP) expectations may seek help from family, friends, or traditional financing. When these traditional modes of raising extra money to cover medical expenses fail, some patients may look to crowdfunding as a source for financial assistance through websites frequently used for business ventures also requiring alternative financing (e.g. GoFundMe ${ }^{\circledR}$, Indiegogo ${ }^{\circledR}$, and Kickstarter $^{\circledR}$ ) [1-4]. In the US, about one in five adults (22\%) have contributed to a crowdfunding campaign of any kind, while approximately $3 \%$ have created their own campaign [5]. Medical crowdfunding, specifically, has grown substantially, with GoFundMe ${ }^{\circledR}$ reporting over 250,000 medical campaigns started each year raising over US\$650 million annually [6]. Despite this rise in popularity, few studies have been conducted to evaluate how patients or caregivers are utilizing these crowdfunding pages, the effectiveness of public fundraising campaigns on access to care, or the role crowdfunding plays in patients seeking alternative therapies or treatments not authorized by their insurer [7-9].

Successful medical crowdfunding campaigns may alleviate or even eliminate the financial burden of expensive, cumulative medical bills. GoFundMe ${ }^{\circledR}$ works by allowing individuals, groups, or organizations to create a campaign, set fundraising goals, disseminate through media channels (emails, text, social media, etc.), accept donations, and thank donors [10]. When creating an online campaign, patients and caregivers frequently discuss financial hardships beyond direct health care costs (inpatient hospitalizations, emergency room visits, outpatient clinic visits, prescriptions, laboratory tests, etc.), such as the inability to work, travel for medical procedures, or other nonhealth care obligations 'piling up' along with the medical expenses [11]. Despite the high-profile stories of successful crowdfunding campaigns that are publicized in the media, about $90 \%$ of campaigns in the US fail to meet their goal, achieving only about $40 \%$ of their requested goal on average [11].

While crowdfunding may offer benefit to some patients, there may be equity concerns when considering it may advantage wealthier patients with the means to utilize online networks, patient groups with higher personal appeal or social standing, or patients with health conditions that may be interpreted as demonstrating a higher level of deservingness $[4,11,12]$. In an analysis of lung cancer crowdfunding pages, authors found that pages that explicitly state the patient was not a smoker were more successful, suggesting a 'blame the victim' attitude may have contributed to fundraising disparities [13]. In addition, beyond advantaging those with more wealth and socioeconomic status, some argue that medical crowdfunding perpetuates systemic injustices [14]. In the case of hepatitis $\mathrm{C}$ virus (HCV) infection, association of the disease with injection drug use, promiscuity, alcohol use, and misinformation about the modes of transmission may lead to stigmatization and a lower personal appeal for potential crowdfunding site donors $[15,16]$. Given the high costs of new medications to treat $\mathrm{HCV}$, many $\mathrm{HCV}$ patients have faced challenges related to OOP costs, as well as insurer limitations or restrictions [17-19]. Some HCV patients report strained relationships with spouses, other family members, friends, and providers as a result of their infection, which could potentially lead to an increased reliance on alternative sources for financial help through crowdfunding [16]. In this study, GoFundMe ${ }^{\circledR}$ medical campaigns for $\mathrm{HCV}$ patients were reviewed and analyzed to better understand the characteristics that contribute to a successful fundraising campaign in a disease often associated with patients with a lower social standing or stigma.

\section{Methods}

\subsection{Study Population}

A cross-sectional study of all publicly available crowdfunding pages was conducted for posts related to HCV on GoFundMe ${ }^{\circledR}$ in June 2019. A single crowdfunding platform was used in this initial pilot to simplify data extraction, and GoFundMe ${ }^{\circledR}$ was selected as the largest crowdfunding platform at the time of this study [20]. An initial search was used to filter pages that contained the term 'hepatitis C' in the page description or title. Page descriptions that were not for patients with a self-reported diagnosis were excluded from the sample.

\subsection{Data}

All data were extracted from GoFundMe ${ }^{\circledR}$ and formatted into a comma-separated values file using Python v.3.7.3. Data included from each page were title, URL, donation received to date, donation goal, page created date, page creator, GoFundMe ${ }^{\circledR}$ page category, location (includes city and state or province), share count, and page description.

Similar to data extraction steps in a systematic literature review, page data were reviewed to identify additional variables, including country (based on location variable), whether the source of the patient's HCV infection was disclosed (yes or no), if the HCV source was disclosed then how did the patient report contracting the disease, and all costs reported in the description as part of the rationale for requesting funds. Furthermore, if the $\mathrm{HCV}$ source was 
disclosed, the research team grouped sources based on social desirability. Viral transmission associated with stigmatized behaviors (injection drug use, needle sharing, sexual transmission) were considered a 'less socially desirable source', while other exposures related to medical procedures (e.g. blood transfusion) or occupation (e.g. needle stick injury, exposure during military service) were considered 'more socially desirable' [21]. All costs reported were further reviewed to create dichotomous variables, including 'direct costs reported' (direct costs related to $\mathrm{HCV}$ ), 'indirect costs reported' (any items not directly related to $\mathrm{HCV}$ ), 'health sector costs' (items typically described in health sector perspective studies, such as medications, office visits, laboratory work, etc.), and 'non-health costs' (including any items mentioned in the page description that were not related to health care). All categorization was conducted by single reviewers (KL, AN, TT) in stages, with review and discussion, as a full research team. Donations received and donation goal variables were reported on GoFundMe ${ }^{\circledR}$ were converted to US dollars for comparison using OANDA Corporation's online currency converter [22].

\subsection{Analyses}

Descriptive statistics of category and numeric variables for the full sample were calculated using Microsoft Excel ${ }^{\circledR}$ (2010). Exploratory Chi-square or Fisher's exact analyses were conducted to determine any potential associations with categorical variables and amount of donations received, categorized as small (<US\$1000), moderate (US\$1000-4999), and large ( $\geq$ US\$5000).

\section{Results}

Searching for 'hepatitis C' within GoFundMe ${ }^{\circledR}$ returned 690 unique pages, with 5 pages excluded for not being related to patients with a self-reported HCV diagnosis, resulting in 685 pages for analysis. Only 30\% (206/685) of the pages disclosed the source of HCV infection. Of those that disclosed a virus source, $86 \%$ (177/206) described a source that appeared more socially desirable to our research team (blood transfusion, organ transplant, occupational exposure, etc.). Actual donations received per page at the time of this search varied widely from US\$0 to US\$166,546, with an average donation received of US\$3330. The number of times a page was shared also varied from 2 to 959 times, with an average number of shares per post of 194 (Table 1).

In terms of actual donations received by a page, $46 \%$ (312/685) were less than US\$1000, 38\% (262/685) were between US\$1000 and US\$5000, and 16\% (111/685) were US\$5000 or more. Disclosing the virus source was associated with a higher donation category $(p=0.0099)$.
Table 1 Descriptive characteristics of crowdfunding webpages related to hepatitis $\mathrm{C}$

\begin{tabular}{lll}
\hline & $N=685$ & $\%$ \\
\hline Country of origin & 605 & 88.0 \\
United States & 80 & 12.0 \\
Other & & \\
Disclosed virus source & 206 & 30.1 \\
Yes & 479 & 69.9 \\
$\quad$ No & & \\
Virus source & \\
$\quad$ Not disclosed & 479 & 69.9 \\
More socially desirable source & 177 & 25.8 \\
$\quad$ Less socially desirable source & 29 & 4.3 \\
Costs reported & & \\
Directly related to disease & 462 & 67.4 \\
Indirectly related to disease & 270 & 39.4 \\
Health care-specific & 490 & 71.5 \\
Non-health care-specific & 435 & 63.5 \\
Quantitative variables [mean (range)] & & \\
Donation amount received (US\$) & 3330 & $0-166,546$ \\
Percentage of goal received & 11 & $0-7510$ \\
Number of shares & 194 & $2-959$ \\
\hline
\end{tabular}

US\$ United States dollars

${ }^{\text {a }}$ Socially desirable sources included medical or occupational exposures

Additionally, pages that provided more information about the types of costs incurred were associated with higher donation categories (Table 2). Patients with HCV pages on GoFundMe ${ }^{\circledR}$ were located all over the world (Fig. 1), with $88 \%(605 / 685)$ being within the US. A page from within the US was not more likely to be associated with a higher donation amount compared with all other countries $(p=0.07)$.

\section{Discussion}

Social desirability represents a significant source of bias in self-reported information as participants seek to present a favorable image, and may impact the validity of observations related to socially sensitive subjects [23, 24]. In the case of GoFundMe ${ }^{\circledR}$ crowdfunding, patients with highly stigmatized conditions may attempt to craft a message or request that reflects this similar type of bias. This study provides additional evidence that there may be disparities and equity concerns with the use of GoFundMe ${ }^{\circledR}$ crowdfunding for health services, as patient groups with less personal appeal or social standing may be further disadvantaged when seeking financial support from the public [4, 11-13]. A large majority of $\mathrm{HCV}$ patients in our sample did not disclose the source of their infection as a component of their page 
Table 2 Country location, virus source disclosure, and cost type inclusion in the GoFundMe listing, by donation size

$\begin{array}{llllll}\begin{array}{l}\text { Small donation } \\ (U S \$ 0-999)\end{array}[N=312] & \text { Moderate donation } & \% & \begin{array}{l}\text { Large donation } \\ (\geq \mathrm{US} \$ 5000) \\ {[N=111]}\end{array} & \% & p \text { value } \\ & {[N=262]} & & & \\ & {[N=00-4999)} & \end{array}$

\begin{tabular}{|c|c|c|c|c|c|c|c|}
\hline \multicolumn{8}{|l|}{ Location } \\
\hline United States & 266 & 85.3 & 239 & 91.2 & 100 & 90.1 & \multirow[t]{2}{*}{0.0702} \\
\hline Other & 46 & 14.7 & 23 & 8.8 & 11 & 9.9 & \\
\hline \multicolumn{8}{|c|}{ Disclosed virus source } \\
\hline Yes & 76 & 24.4 & 89 & 34.0 & 41 & 36.9 & \multirow[t]{2}{*}{$0.0099^{\mathrm{a}}$} \\
\hline No & 236 & 75.6 & 173 & 66.0 & 70 & 63.1 & \\
\hline \multicolumn{8}{|c|}{ Cost types included } \\
\hline \multicolumn{8}{|l|}{ Direct costs } \\
\hline Yes & 172 & 55.1 & 200 & 76.3 & 90 & 81.1 & \multirow[t]{2}{*}{$<0.0001^{\mathrm{a}}$} \\
\hline No & 140 & 44.9 & 62 & 23.7 & 21 & 18.9 & \\
\hline \multicolumn{8}{|l|}{ Indirect costs } \\
\hline Yes & 74 & 23.7 & 132 & 50.4 & 64 & 57.7 & \multirow[t]{2}{*}{$<0.0001^{\mathrm{a}}$} \\
\hline No & 238 & 76.3 & 130 & 49.6 & 47 & 42.3 & \\
\hline \multicolumn{8}{|l|}{ Health costs } \\
\hline Yes & 186 & 59.6 & 213 & 81.3 & 91 & 82.0 & \multirow[t]{2}{*}{$<0.0001^{\mathrm{a}}$} \\
\hline No & 126 & 40.4 & 49 & 18.7 & 20 & 18.0 & \\
\hline \multicolumn{8}{|c|}{ Non-health costs } \\
\hline Yes & 181 & 58.0 & 171 & 65.3 & 83 & 74.8 & \multirow[t]{2}{*}{$0.0052^{\mathrm{a}}$} \\
\hline No & 131 & 42.0 & 91 & 34.7 & 28 & 25.2 & \\
\hline
\end{tabular}

${ }^{\mathrm{a}}$ Significant at alpha $<0.05$

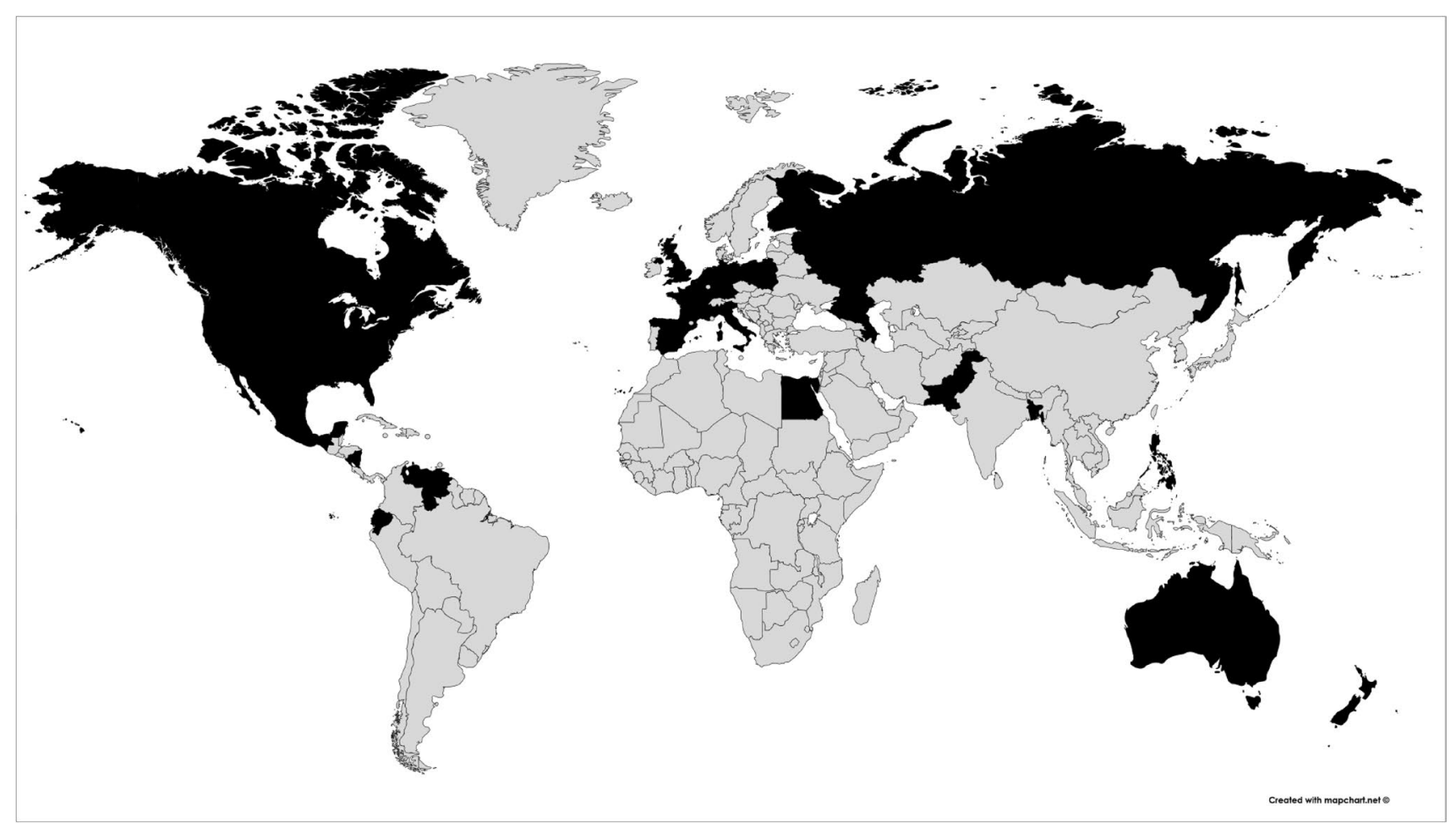

Fig. 1 Countries with a GoFundMe listing related to Hepatitis C 
description. Of the $206 \mathrm{HCV}$ patients who did disclose the source of their viral infection, only $29(14 \%)$ described contracting the virus through a socially undesirable exposure, such as injecting drugs, sexual contact, or needle sharing. GoFundMe ${ }^{\circledR}$ pages that included a description of how the patients were exposed to the virus and included more information about all costs were associated with higher levels of donations received. This supports the notion that patients seeking financial support for medical conditions on crowdfunding sites are attempting to make a case demonstrating 'deservingness', and avoid disclosing information that may lead to potential donors to 'blame the victim' when searching pages to support [13].

In our sample, the majority of pages included costs directly associated with HCV disease, while fewer pages included costs that were considered indirect costs of having the disease. Direct costs focused on items such as medications, surgery, and transportation to receive care, while indirect costs included a wide range of costs that had no explicit connection to HCV (e.g. 'making ends meet while raising two kids'; 'home for family'; 'chemotherapy for unrelated cancer'). The majority of pages included both health-related and non-health-related costs. Health-related costs included expenses HCV patients typically encounter (medications, clinic visits, hospitalizations, surgery, etc.), while non-health costs focused primarily on other common necessary living expenses (transportation, housing, etc.). In a few cases, pages were seeking help to cover funeral expenses for a recently deceased relative with HCV. Typically, economic evaluations focused on 'health sector' costs fail to include funeral expenses as this often falls outside the medical or pharmacy benefit, but these costs are very real to patients and families.

Our study has several limitations that should be considered when evaluating the results presented and when researchers attempt to use this type of data. First, the sample was collected exclusively from GoFundMe ${ }^{\circledR}$ and does not include data from other medical crowdfunding websites. These findings are not generalizable to other medical crowdfunding sites, or to regions or countries who rely on other medical crowdfunding websites or collaborative ways to raise medical funds. The issue of social desirability bias certainly applies to this cross-sectional sample. We report that $177(86 \%)$ GoFundMe ${ }^{\circledR}$ pages that disclosed a virus source presented more socially desirable exposures for their condition. Any conclusions related to self-reporting of viral exposure must be taken in the context of the presence of this type of bias, along with the unknown number of patients who choose not to create a GoFundMe ${ }^{\circledR}$ page for financial assistance who may fear their situations do not conform to socially acceptable values [24]. For this reason, we chose to present our pilot findings in a descriptive fashion and conducted exploratory tests to provide some foundation for others considering this type of data as a source of selfreported financial information. There is a lack of understanding and need for more research around how type of illness impacts the funds raised, and if certain health conditions are considered more socially desirable when engaging with medical fundraising. In addition, future efforts studying medical crowdfunding should address the ethical implications of widening funding disparities and impacts on health equity and access to health care. Finally, our review process of each post was conducted by single reviewers for this pilot, and we discussed the reviews as a team to achieve team consensus; however, we did not record or assess disagreements to assess the validity or reliability of our process. We felt sharing our initial pilot using this publicly available data at this stage may provide value to researchers from a feasibility and hypothesis-generating perspective.

Our study aimed to review and assess existing crowdfunding campaigns for a single medical condition to gain a better understanding of this publicly available data and how individuals with $\mathrm{HCV}$ were using this type of platform for financial support. Future researchers and policymakers may consider questions such as "What effect does crowdfunding or the availability of crowdfunding have on patient access to care?" or "Does the increase in patients in the United States resorting to crowdfunding for care have any impact on the advocacy for health reform?". While the phenomenon of online campaigning for financial support on sites such as GoFundMe ${ }^{\circledR}$ has been a recent development, health care financing with cost sharing and patient OOP obligations have been around much longer.

Despite the limitations we have noted, the study uncovers important information about attitudes towards giving. Disclosing any virus source was associated with higher donation amounts. In addition, patients who employed narratives of financial need were significantly associated with greater funds raised when they disclosed information about the types of direct and indirect costs. Describing health and non-health costs was also associated with higher donation levels. While describing the types of costs patients experience may provide a stronger case for need, we did not evaluate the quality of the post's description or other variables that may influence this relationship.

\section{Conclusions}

These findings yield important insights, both for patients or caregivers seeking support on crowdfunding websites and for researchers interested in exploring the types of costs self-reported by patients in their public requests for financial assistance. Policymakers should consider the difficulty patients with less socially desirable conditions, such as HCV, 
often face requesting financial support when determining levels of OOP liabilities.

Acknowledgements The authors would like to thank Aabesh Karmacharya for coding and data-mining services to extract the data.

\section{Declarations}

Funding No funding was received for this study.

Conflicts of interest T. Joseph Mattingly II reports consultant fees from G\&W Labs, BMS, PhRMA, and NHC, all unrelated to this research. KL, AN, TT, and JO report no conflicts of interests.

Data Availability Statement The datasets generated and/or analyzed during the current study are available from the corresponding author upon reasonable request. All GoFundMe ${ }^{\circledR}$ posts are publicly available but the posts used for this study may only be online during a specified time.

Author contributions Study concept and design: All authors. Drafting of the manuscript: TJM. Critical reviews: All authors. Statistical analysis: TJM. Interpretation of data: All authors. Approval of the final version: All authors.

Open Access This article is licensed under a Creative Commons Attribution-NonCommercial 4.0 International License, which permits any non-commercial use, sharing, adaptation, distribution and reproduction in any medium or format, as long as you give appropriate credit to the original author(s) and the source, provide a link to the Creative Commons licence, and indicate if changes were made. The images or other third party material in this article are included in the article's Creative Commons licence, unless indicated otherwise in a credit line to the material. If material is not included in the article's Creative Commons licence and your intended use is not permitted by statutory regulation or exceeds the permitted use, you will need to obtain permission directly from the copyright holder. To view a copy of this licence, visit http://creativecommons.org/licenses/by-nc/4.0/.

\section{References}

1. GoFundMe. About GoFundMe. 2020. https://www.gofundme. com/c/about-us. Accessed 9 Jan 2020.

2. Indiegogo. About Us. 2020. https://www.indiegogo.com/about/ our-story. Accessed 9 Jan 2020.

3. Kickstarter. About us. 2020. https://www.kickstarter.com/about ?ref=global-footer. Accessed 9 Jan 2020.

4. Young MJ, Scheinberg E. The rise of crowdfunding formedical care promises and perils. JAMA. 2017;317(16):1623-4. https:// doi.org/10.1001/jama.2017.3078.

5. Smith A. Shared, Collaborative and On Demand: The New Digital Economy. Pew Research Center. 2016. https://www.pewresearc h.org/internet/2016/05/19/the-new-digital-economy/. Accessed 9 Jan 2020.

6. GoFundMe. Get help with medical fundraising. 2020. https:// www.gofundme.com/start/medical-fundraising. Accessed 9 Jan 2020 .
7. Snyder J, Mathers A, Crooks VA. Fund my treatment! A call for ethics-focused social science research into the use of crowdfunding for medical care. Soc Sci Med. 2016;169:27-30. https://doi. org/10.1016/j.socscimed.2016.09.024.

8. Vox F, Folkers KM, Turi A, Caplan AL. Medical crowdfunding for scientifically unsupported or potentially dangerous treatments. JAMA. 2018;320(16):1705-6.

9. Snyder J, Caulfield T. Patients' crowdfunding campaigns for alternative cancer treatments. Lancet Oncol. 2019;20(1):28-9. https:// doi.org/10.1016/S1470-2045(18)30950-1.

10. GoFundMe. How GoFundMe Works. 2020. https://www.gofun dme.com/c/how-it-works. Accessed 1 Aug 2020.

11. Berliner LS, Kenworthy NJ. Producing a worthy illness: personal crowdfunding amidst financial crisis. Soc Sci Med. 2017;187:23342. https://doi.org/10.1016/j.socscimed.2017.02.008.

12. Van Duynhoven A, Lee A, Michel R, et al. Spatially exploring the intersection of socioeconomic status and Canadian cancer-related medical crowdfunding campaigns. BMJ Open. 2019;9(6):1-10. https://doi.org/10.1136/bmjopen-2018-026365.

13. Nguyen R, Hanna NH, Vater L. Crowdfunding for lung cancer costs. J Clin Oncol. 2019;37(15 suppl):e18340. https://doi. org/10.1200/JCO.2019.37.15_suppl.e18340.

14. Snyder J. Crowdfunding for Medical Care: Ethical Issues in an Emerging Health Care Funding Practice. Hastings Cent Rep. 2016;46(6):36-42. https://doi.org/10.1002/hast.645.

15. Sublette VA, Smith SK, George J, McCaffery K, Douglas MW. The Hepatitis C treatment experience: Patients' perceptions of the facilitators of and barriers to uptake, adherence and completion. Psychol Health. 2015;30(8):987-1004. https://doi. org/10.1080/08870446.2015.1012195.

16. Mhatre SK, Sansgiry SS. Development of a conceptual model of health-related quality of life among hepatitis $C$ patients: a systematic review of qualitative studies. Hepatol Res. 2016;46(1):29-39. https://doi.org/10.1111/hepr.12521.

17. Chidi AP, Bryce CL, Donohue JM, et al. Economic and Public Health Impacts of Policies Restricting Access to Hepatitis C Treatment for Medicaid Patients. Value Health. 2016;19(4):32634. https://doi.org/10.1016/j.jval.2016.01.010.

18. Jung JK, Feldman R, Cheong C, Du P, Leslie D. Coverage for hepatitis $\mathrm{C}$ drugs in Medicare Part D. Am J Manag Care. 2016;22(6):SP220-SP226.

19. Mattingly TJ II, Slejko JF, Perfetto EM, Kottilil S, Mullins CD. What matters most for treatment decisions in hepatitis c: effectiveness, costs, and altruism. Patient. 2019;12(6):631-8. https://doi. org/10.1007/s40271-019-00378-7.

20. Cerullo M. As medical costs soar, more Americans turn to crowdfunding. CBS News. 21 Feb 2020. https://www.cbsnews.com/ news/health-care-costs-crowdfunding-medical-bills/. Accessed 1 Aug 2020

21. Hagan H, Pouget ER, Williams IT, et al. Attribution of hepatitis $\mathrm{C}$ virus seroconversion risk in young injection drug users in 5 US cities. J Infect Dis. 2010;201(3):378-85. https://doi. org/10.1086/649783.

22. OANDA Corporation. Currency Converter. 2019. https://www1. oanda.com/currency/converter/. Accessed 30 June 2019.

23. Fisher RJ, Katz JE. Social-desirability bias and the validity of self-reported values. Psychol Mark. 2000;17(2):10520. https ://doi.org/10.1002/(SICI)1520-6793(20000 2) 17:2<105:AID-MAR3>3.0.CO;2-9.

24. van de Mortel TF. Faking it: social desirability response bias in selfreport research. Aust J Adv Nurs. 2008;25(4):40-8. 